\title{
HUBUNGAN PENGETAHUAN DAN SIKAP AKSEPTOR KB AKTIF TENTANG KONTRASEPSI IMPLAN DI DESA DOKO KECAMATAN NGASEM KABUPATEN KEDIRI
}

Susiani Endarwati ${ }^{1}$. Eka Sulistyadini Saputri ${ }^{2}$

Akademi Kebidanan Dhara Husada Kediri

\begin{abstract}
ABSTRAK
Kontrasepsi dibutuhkan untuk membatasi jumlah penduduk. Masyarakat banyak yang sudah mengetahui mengenai keluarga berencana, namun hanya beberapa orang saja yang tertarik untuk menggunakan kontasepsi implan. Hal ini karena kurangnya pengetahuan masyarakat tentang kontrasepsi implan dan dalam menyikapi kontrasepsi implan. Tujuan penelitian ini adalah untuk mengetahui hubungan pengetahuan dan sikap akseptor KB aktif tentang kontrasepsi implan di BPM Ny. Agustin Desa Doko, Kecamatan Ngasem Kabupaten Kediri.

Jenis rancangan penelitian ini adalah penelitian korelasi dengan pendekatan cross sectional. Populasi dalam penelitian ini adalah semua akseptor KB aktif. Tehnik pengambilan sampel dengan accidental sampling didapatkan sampel 30 responden. Penelitian dilakukan pada tanggal 7-15 Mei 2015. Pengambilan data dengan menggunakan kuesioner, data diolah dengan editing, coding, scoring, tabulating dan dianalisis dengan uji chi square.

Hasil penelitian menunjukkan responden dengan pengetahuan baik adalah 18 responden (60\%), dan pengetahuan kurang 12 responden (40\%). Sedangkan sikap akseptor KB aktif tentang kontrasepsi implan dalam kategori positif adalah 17 responden (56, 7\%). Hasil uji statistik dengan menggunakan chi square, diperoleh hasil chi square $=0,016<0,05$ maka $_{0}$ ditolak.

Dari hasil penelitian diperoleh kesimpulan bahwa Ada Hubungan Pengetahuan dan Sikap Akseptor KB Aktif tentang kontrasepsi implan. Dengan demikian diharapkan akseptor $\mathrm{KB}$ lebih termotivasi untuk menambah informasi dan pengetahuan tentang kontrasepsi implan melalui tenaga kesehatan, media massa, dan kader serta dapat mengaplikasikan pengetahuan dalam kehidupan sehari-hari.
\end{abstract}

\section{Kata Kunci : Pengetahuan, Sikap, Kontrasepsi Implan, Akseptor KB}




\section{PENDAHULUAN}

Indonesia merupakan salah satu negara berkembang dengan salah satu permasalahannya yaitu masih tingginya pertumbuhan penduduk. Laju pertumbuhan penduduk Indonesia di periode 2000-2010 dibandingkan periode 1990-2010 mengalami peningkatan sebesar $1,49 \%$ per tahun. Semakin tinggi laju pertumbuhan penduduk menyebabkan jumlah penduduk semakin banyak di masa yang akan datang. Hal tersebut menunjukkan ketidakberhasilan dari program pemerintah dalam menekan laju pertumbuhan penduduk melalui program Keluarga Berencana (KB). (Dinkes RI, 2011)

$\mathrm{KB}$ adalah sebagai suatu usaha yang mengatur banyaknya kehamilan sedemikian rupa sehingga berdampak positif bagi ibu, bayi, ayah serta keluarganya yang bersangkutan tidak akan menimbulkan kerugian sebagai akibat langsung dari kehamilan tersebut (Suratun dkk, 2008 :19).

Kontrasepsi dibutuhkan untuk membatasi jumlah penduduk dan menjamin ketersediaan sumber daya alam sehingga menjaga kualitas hidup manusia. Masyarakat kebanyakan menggunakan metode kontrasepsi yang efektivitasnya pendek seperti pil dan suntik. Hal ini terjadi karena kurangnya pengetahuan masyarakat tentang kontrasepsi implan dan dalam menyikapi kontrasepsi implan. Salah satunya kebanyakan masyarakat masih beranggapan bahwa implan/susuk dapat hilang sendiri dari tubuh atau berpindah sendiri ke anggota tubuh yang lain.

Implan adalah kontrasepsi jangka panjang yang menggunakan kapsul levonorgestrel fleksibel dan ditanam pada subdermal dengan prosedur operasi kecil. Kontrasepsi ini efektif untuk lima tahun. (Purwandari, 2010 : 131).

Tingkat pengetahuan masyarakat akan kontrasepsi sudah tinggi (97,5\%) namun baru sebatas mampu menyebut jenis alat dan obat kontasepsi, tetapi belum dapat menyebutkan efek samping, kontraindikasi, kelebihan dan kekurangan. Padahal informasi ini penting difahami sebelum memutuskan menggunakan alat kontrasepsi tertentu. (BKKBN, 2007). Alasan inilah yang membuat para akseptor KB dalam memilih alat kontrasepsi belum berbasis pada rasional, efektivitas, dan efisien.

Indonesia pada tahun 2012 tercatat jumlah peserta KB aktif dari 64.133.347 juta jiwa, dengan jumlah Pasangan Usia Subur (PUS) 161.750.743 juta jiwa dan Wanita Usia Subur (WUS) 51.472.069 juta jiwa. Dari data BKKBN Jawa Timur, tercatat sampai dengan pada bulan September 2012 sebanyak 91.242 peserta IUD, 21.415 peserta MOW, 107.242 peserta implan, dan 2.423 peserta MOP. (BKKBN, 2012). Sedangkan pada Kabupaten Kediri, jumlah akseptor KB aktif sebanyak 821.391 peserta. Dengan persentase sebagai berikut : 20.160 peserta IUD (9,3\%), 10.402 peserta MOW $(4,8 \%), 9.801$ peserta implant $(4,5 \%)$, 147.719 peserta suntikan $(68,1 \%), 26.412$ peserta pil $(12,2 \%), 605$ peserta MOP $(0,3 \%)$ dan 1.897 peserta kondom $(0,9 \%)$. (BKKBN, 2012).

Hasil studi pendahuluan yang dilakukan pada 16 Maret 2015, pada 10 responden dengan membagikan kuisioner mengenai pengetahuan ibu tentang kontrasepsi implan, jenis kontrasepsi implan, efek samping implan, indikasi implan, kontraindikasi implan, kelebihan dan kekurangan implan, serta cara kerja implan. Hanya 20\% ibu yang memiliki pengetahuan baik. Dan sebanyak $80 \%$ ibu tidak mengetahui kontrasepsi implan serta tidak mendukung metode kontrasepsi jangka panjang dengan alasan sakit pada waktu pemasangannya, dan biayanya mahal. Masyarakat belum mempunyai keinginan untuk mengganti metode kontrasepsi yang mereka gunakan ke metode kontrasepsi jangka panjang implan, karena mereka belum mengetahui secara detail mengenai kontrasepsi implan. 
kontrasepsi implan.

\section{METODE}

Jenis rancangan yang digunakan dalam penelitian ini adalah penelitian korelasi dengan pendekatan cross sectional. Populasi dalam penelitian ini adalah semua akseptor KB aktif di BPM Ny. Agustina Desa Doko Kecamatan Ngasem Kabupaten Kediri sebanyak 62 orang.

Sampel dalam penelitian ini adalah akseptor KB aktif yang datang periksa yang memenuhi kriteria inklusi di BPM Ny. Agustina Desa Doko Kecamatan Ngasem Kabupaten Kediri sebanyak 30 orang. Kriteria inklusi dalam penelitian ini

a. Semua akseptor KB aktif di BPM Ny. Agustina yang bersedia menjadi responden. b. Akseptor KB aktif yang datang periksa di BPM Ny. Agustina yang bisa baca tulis.

Teknik sampling yang digunakan dalam penelitian ini adalah Accidental Sampling. Accidental Sampling. Variabel dalam penelitian ini adalah variabel independen dan variabel dependen :

1. Variabel Independen dalam penelitian ini yaitu pengetahuan ibu tentang kontrasepsi implan

2. Variabel dependen dalam penelitian ini yaitu sikap ibu terhadap kontrasepsi implan.

Tabel III.1 Hubungan Pengetahuan dan Sikap Akseptor KB Aktif tentang Kontrasepsi Implan di BPM Ny. Agustina

\begin{tabular}{|c|c|c|c|c|c|}
\hline Variabel & $\begin{array}{l}\text { Definisi } \\
\text { Operasional }\end{array}$ & Parameter & $\begin{array}{l}\text { Alat } \\
\text { Ukur }\end{array}$ & Skala & Kriteria \\
\hline $\begin{array}{l}\text { Pengetahuan } \\
\text { akseptor KB } \\
\text { tentang } \\
\text { kontrasepsi } \\
\text { implan. }\end{array}$ & $\begin{array}{l}\text { Segala sesuatu } \\
\text { yg diketahuioleh } \\
\text { akseptor KB ttg } \\
\text { kontra-sepsi } \\
\text { implan di BPM } \\
\text { Ny. Agustina } \\
\text { Desa Doko } \\
\text { Kecamatan } \\
\text { Ngasem Kabupaten } \\
\text { Kediri. }\end{array}$ & \begin{tabular}{cl}
\multicolumn{3}{l}{ Jawaban Responden: } \\
1. & Definisi implan \\
2. & Jenis-jenis kontrasepsi \\
& Implan \\
3. & Mekanisme kerja Implan \\
4. & Efektivitas Implan \\
5. & Efek samping Implan \\
6. & Keuntungan Implan \\
7. & Kerugian Implan \\
8. & Indikasi Implan \\
9. & Kontraindikasi Implan
\end{tabular} & $\begin{array}{l}\mathrm{K} \\
\mathrm{U} \\
\mathrm{E} \\
\mathrm{S} \\
\mathrm{I} \\
\mathrm{O} \\
\mathrm{N} \\
\mathrm{E} \\
\mathrm{R}\end{array}$ & $\begin{array}{c}\mathrm{N} \\
\mathrm{O} \\
\mathrm{M} \\
\mathrm{I} \\
\mathrm{N} \\
\mathrm{A} \\
\mathrm{L}\end{array}$ & $\begin{array}{l}\text { Skor: } \\
\text { Pernyataan positif: } \\
\text { Benar (1) } \\
\text { Salah (0) } \\
\text { Pernyataan negatif: } \\
\text { Benar (0) } \\
\text { Salah (1) } \\
\text { Kriteria : } \\
\text { Baik : hasil > 50\% } \\
\text { Kurang baik : hasil } \leq \\
50 \% \\
\text { (Budiman \& Agus, } \\
2013: 11)\end{array}$ \\
\hline
\end{tabular}




\begin{tabular}{|c|c|c|c|c|c|}
\hline $\begin{array}{l}\text { Sikap } \\
\text { akseptor KB } \\
\text { terhadap } \\
\text { kontrasepsi } \\
\text { implan. }\end{array}$ & $\begin{array}{l}\text { Reaksi perasaan } \\
\text { akseptor KB } \\
\text { terhadap metode } \\
\text { konstrasepsi } \\
\text { implan di BPM } \\
\text { Ny. Agustina } \\
\text { Desa Doko } \\
\text { Kecamatan } \\
\text { Ngasem } \\
\text { Kabupaten } \\
\text { Kediri. }\end{array}$ & $\begin{array}{l}\text { Indikator sikap terhadap } \\
\text { kontrasepsi implan : } \\
\text { 1. Kognitif } \\
\text { Pendapat akseptor tentang } \\
\text { kontrasepsi implan. } \\
\text { 2. Afektif } \\
\text { Perhatian akseptor tentang } \\
\text { kontrasepsi implan. } \\
\text { 3. Konatif } \\
\text { Respon akseptor tentang } \\
\text { kontrasepsi implan. }\end{array}$ & $\begin{array}{c}\mathrm{K} \\
\mathrm{U} \\
\mathrm{E} \\
\mathrm{S} \\
\mathrm{I} \\
\mathrm{O} \\
\mathrm{N} \\
\mathrm{E} \\
\mathrm{R}\end{array}$ & $\begin{array}{c}\mathrm{N} \\
\mathrm{O} \\
\mathrm{M} \\
\mathrm{I} \\
\mathrm{N} \\
\mathrm{A} \\
\mathrm{L}\end{array}$ & $\begin{array}{l}\text { Skor : } \\
\text { Skor untuk pernya- } \\
\text { taan positif }(+): \\
\text { STS : } 1 \\
\text { TS : } 2 \\
\text { S : } 3 \\
\text { SS : } 4 \\
\text { Skor untuk pernya- } \\
\text { taan negatif }(-): \\
\text { STS : } 4 \\
\text { TS : } 3 \\
\text { S : } 2 \\
\text { SS : } 1 \\
\text { Kriteria : } \\
\text { Positif:Jika skor } \mathrm{T} \geq \\
\text { mean T } \\
\text { Negatif:Jika skor T< } \\
\text { mean T } \\
\text { (Azwar, } 2013: 156)\end{array}$ \\
\hline
\end{tabular}

Instrumen yang digunakan pada penelitian ini adalah kuesioner bersifat tertutup. Uji statistik yang digunakan dalam penelitian ini adalah teknik uji Chi kuadrat (Chi Square). $x^{2}=\frac{\sum(f o-f h)^{2}}{f h}$

Keterangan:

$x^{2}=$ chi kuadrat

Fo $=$ frekuensi yang diobservasi

$\mathrm{Fh}=$ frekuensi harapan

(Sugiyono, $2010: 107$

\section{HASIL}

1. Pengetahuan Akseptor KB Aktif tentang kontrasepsi Implan

Tabel IV.1 Distribusi Frekuensi Pengetahuan Akseptor KB Aktif tentang kontrasepsi Implan di BPM Ny. Agustin Desa Doko, Kecamatan Ngasem Kabupaten Kediri

\begin{tabular}{ccccc} 
No & Pengetahuan & Jumlah & Persentase (\%) \\
\hline 1. & Baik & 18 & 60 \\
\hline 2. & Kurang & & 12 & 40 \\
\hline & & Jumlah & 30 & 100
\end{tabular}

Berdasarkan tabel IV.6 dapat menunjukkan dari 30 responden yang diteliti, terdapat 18 responden $(60 \%)$ berpengatuhan baik, dan 12 responden $(40 \%)$ berpengetahuan kurang.

\section{Sikap Akseptor KB Aktif tentang kontrasepsi Implan.}

Tabel IV.2 Distribusi Frekuensi Sikap Akseptor KB Aktif tentang kontrasepsi Implan di BPM Ny. Agustin Desa Doko, Kecamatan Ngasem Kabupaten Kediri

\begin{tabular}{clccc} 
No & & Sikap & Jumlah & Prosentase (\%) \\
\hline 1 & Positif & 17 & 57 \\
\hline 2 & \multirow{2}{*}{ Negatif } & 13 & 43 \\
\hline \multicolumn{2}{r}{ Jumlah } & 30 & 100
\end{tabular}

44 | Jurnal Kebidanan Dharma Husada Vol. 4, No. 2 Oktober 2015 
Berdasarkan tabel IV.7 dapat menunjukkan dari 30 responden yang diteliti, terdapat 17 responden (57\%) memiliki sikap positif, dan 13 responden (43\%) memiliki sikap negatif.

\section{Tabulasi Silang Hubungan Pengetahuan dengan Sikap Akseptor KB Aktif tentang kontrasepsi Implan}

Tabel IV.8 Tabel Silang Hubungan Pengetahuan dengan Sikap Akseptor KB Aktif tentang kontrasepsi Implan di BPM Ny. Agustin Desa Doko, Kecamatan Ngasem Kabupaten Kediri

\begin{tabular}{ccccccc}
\multirow{2}{*}{ Pengetahuan } & Sikap & \multicolumn{2}{c}{ Positif } & \multicolumn{2}{c}{ Negatif } & \multirow{2}{*}{ Jumlah } \\
\cline { 2 - 6 } & $\sum$ & \% & $\sum$ & \% & 18 \\
\hline Baik & 7 & 23 & 11 & 37 & 12 \\
\hline Kurang & 10 & 33 & 2 & 7 & 30
\end{tabular}

Dari tabel IV.8 dapat diketahui bahwa dari 30 responden:

a. Responden yang mempunyai pengetahuan baik dengan sikap akseptor KB positif sebanyak 7 responden (23\%), sedangkan yang berpengetahuan baik dengan sikap akseptor KB negatif sebanyak 11 responden $(37 \%)$.

b. Responden yang mempunyai pengetahuan kurang dengan sikap akseptor KB positif sebanyak 10 responden (33\%), sedangkan yang berpengetahuan kurang dengan sikap akseptor KB negatif sebanyak 2 responden (7\%).

\section{Diskusi}

1. Pengetahuan Akseptor KB Aktif tentang Kontrasepsi Implan

Berdasarkan pada tabel penelitian yang terdapat pada tabel IV.6 dapat menunjukkan dari 30 responden yang diteliti, terdapat 18 responden $(60 \%)$ berpengetahuan baik, dan 12 responden $(40 \%)$ berpengetahuan kurang.

Sebagian besar reponden memiliki pengetahuan baik tentang kontrasepsi implan. Namun masih adanya responden yang memiliki pengetahuan dalam kategori kurang, yaitu sebanyak 40\% dikarenakan beberapa hal yang mempengaruhi antara lain informasi yang kurang mengenai alat kontrasepsi beserta efek samping, kontraindikasi, kekurangan, dan kelebihan.

Beberapa ibu sangat jarang mengikuti acara-acara penyuluhan mengenai keluarga berencana. Hanya ibu-ibu yang menjadi kader PKK saja yang aktif mengikuti acara tersebut. Sosialisasi dari kader PKK yang aktif mengikuti acara penyuluhan kepada ibu yang tidak aktif belum efektif diberikan sehingga pemahaman ibu mengenai alat kontrasepsi kurang. Rata-rata ibu mendapat informasi mengenai alat kontrasepsi dengan cara bertukar pikiran atau pendapat, serta pengalaman.

Salah satu faktor yang dapat mempengaruhi pengetahuan adalah tingkat pendidikan akseptor. Berdasarkan tabel IV.2 dapat menunjukkan dari 30 responden yang diteliti, terdapat 10 responden $(33 \%)$ sebagian besar berpendidikan SMP, dan 5 responden $(17 \%)$ sebagian kecil Perguruan tinggi. 
Semakin tinggi tingkat pendidikan seseorang diharapkan penalaran serta pemahaman akan sesuatu yang terjadi di sekitarnya semakin peka dan baik, sehingga apabila terjadi hal yang dirasa kurang sesuai dapat langsung merespon dengan baik. Pendidikan ini termasuk pengaruh utama dalam pengetahuan, pengetahuan seseorang akan semakin luas tergantung pada tingkat pendidikan yang diperoleh orang tersebut.

Dengan pendidikan pula seseorang dapat menilai sesuatu hal dari berbagai aspek misalnya dalam memilih kontrasepsi implan, pada akseptor yang berpendidikan tinggi, cenderung lebih bisa memahami dalam hal definisi dan manfaat dari kontrasepsi implan, berbeda dengan akseptor yang berpendidikan kurang, akseptor dengan pendidikan kurang biasanya cenderung kurang memahami, hal ini juga dikarenakan tingkat ilmu yang di dapat lebih banyak pada akseptor yang mengenyam tingkat pendidikan yang lebih tinggi.

Dari hasil penelitian sebagian akseptor KB yang menjadi responden memiliki pengetahuan baik tentang kontrasepsi implan salah satu yang menunjukkan bahwa pengetahuan responden dalam kriteria baik adalah kuesioner nomor 2 dalam soal tersebut dinyatakan "Implan adalah metode kontrasepsi yang dipakai di lengan atas bagian sebelah dalam" yang termasuk pernyataan positif, dari 30 responden di dapat 23 responden (77\%) yang menjawab benar tentang pernyataan tersebut. Pengetahuan yang baik tentang kontrasepsi implan jika tidak di ikuti dengan aplikasi yang benar dan nyata tidak akan mempunyai dampak yang positif dalam membantu pencapaian target penggunaan implan.

Hal ini dikarenakan akseptor $\mathrm{KB}$ sebagian besar lebih mengetahui tentang kekurangan implan daripada kelebihan atau keuntungannya. Sehingga masih banyak yang belum berminat untuk menggunakan implan. Padahal kelebihan implan jauh lebih banyak dibandingkan kekurangannya.

Selain itu faktor lain yang dapat mempengaruhi pengetahuan adalah umur. Berdasarkan tabel IV.1 dapat menunjukkan dari 30 responden yang diteliti, terdapat 14 responden $(47 \%)$ sebagian besar berumur 21-30 tahun dan 5 responden (17\%) sebagian kecil berumur $>40$ tahun.

Semakin cukup umur tingkat kematangan dan kekuatan seseorang akan lebih matang dalam berfikir. Dari segi kepercayaan masyarakat yang lebih dewasa akan lebih dipercayai dari orang yang belum cukup kedewasaannya. Contoh saja dalam memilih kontrasepsi implan. Masyarakat masih banyak yang cenderung mempercayai hal-hal yang tidak nyata seperti implan dapat hilang sendiri, atau berjalan ke anggota tubuh yang lain.

Kedewasaan dalam berfikir sangat diperlukan dalam hal menyikapi kontrasepsi implan, usia akseptor dapat mempengaruhi pola pemikiran dalam pemilihan kontrasepsi implan akan tetapi tidak menutup kemungkinan pengetahuan akseptor dengan usia yang masih muda cenderung acuh terhadap kontrasepsi implan, hal ini di karenakan pengalaman yang kurang pada akseptor usia muda.

Sebaiknya memperhatikan penyebab terjadinya kenapa pengguna implan jumlahnya sedikit. Hal ini sangat penting, agar tidak terjadi kesalahan persepsi tentang kontrasepsi implan yang berlarut-larut. Pengaruh kesalahan persepsi yang berulang dapat menambah jumlah penurunan penggunaan implan.

Saran yang tepat bagi akseptor diharapkan aktif dalam mengikuti kegiatan posyandu di daerah setempat serta berkonsultasi pada bidan tentang kontrasepsi yang cocok baginya. Adapun untuk petugas kesehatan agar lebih sering melakukan penyuluhan tentang alat kontrasepsi. 
Ada satu lagi faktor yang dapat mempengaruhi sikap akseptor yaitu pekerjaan. Berdasarkan tabel IV.3 dapat menunjukkan dari 30 responden yang diteliti, terdapat 15 responden $(50 \%)$ sebagian besar sebagai IRT, dan 1 responden (3\%) sebagian kecil sebagai PNS.

Lingkungan pekerjaan dapat membuat seseorang memperoleh pengalaman dan pengetahuan, baik secara langsung maupun tidak langsung. (Mubarak, 2011:83).

Pekerjaan akseptor dapat mempengaruhi pengetahuan seseorang. Sebagai contoh IRT, akseptor yang memiliki pekerjaan sebagai IRT cenderung pengetahuannya lebih sedikit daripada seseorang yang memiliki pekerjaan sebagai wiraswasta, swasta, dan PNS.

Jumlah IRT dari `15 responden hanya 4 responden (27\%) yang memiliki pengetahuan baik. Hal ini karena IRT cenderung di rumah sehingga kurang memiliki pengalaman untuk bertukar pengetahuan kepada orang lain.

\section{Sikap Akseptor KB Aktif tentang Kontrasepsi Implan}

Berdasarkan tabel IV.7 dapat menunjukkan dari 30 responden yang diteliti, terdapat 17 responden $(57 \%)$ memiliki sikap positif, dan 13 responden (43\%) memiliki sikap negatif.

Sikap (attitude) merupakan konsep paling penting dalam psikologi sosial yang membahas unsur sikap baik sebagian individu maupun kelompok. Banyak kajian dilakukan untuk merumuskan pengertian sikap, proses terbentuknya sikap, maupun perubahan (Wawan , 2010:19).

Selain itu faktor yang dapat mempengaruhi sikap akseptor terhadap kontrasepsi implan adalah informasi. Berdasarkan tabel IV.4 dapat menunjukkan dari 30 responden yang diteliti, terdapat 23 responden (77\%) sudah mendapat informasi, dan 7 responden $(23 \%)$ belum pernah mendapat informasi.

Informasi merupakan sekumpulan fakta-fakta yang telah dilah menjadi bentuk data, sehingga akan menjadi lebih berguna dan dapat digunakan oleh siapa saja yang membutuhkan data-data tersebut sebagai pengetahuan ataupun dapat digunakan dalam pengambilan keputusan. Pada kemajuan teknologi yang semakin canggih ini, dapat mempengaruhi sikap seseorang dalam memperoleh suatu informasi. Berbagai informasi saat ini sangat mudah dan cepat didapat, misalnya informasi terhadap kontrasepsi implan.

Dari hasil penelitian yang sudah dilakukan, 18 responden sudah pernah mendapat informasi tentang kontrasepsi implan. Tetapi hal tersebut juga tidak berpengaruh terhadap baiknya sikap akseptor tentang kontrasepsi implan, karena bisa saja hanya sekilas saat memperoleh informasi tentang kontrasepsi implan.

Dalam penelitian ini dapat diketahui bahwa jumlah sikap positif sebanyak 17 responden (57\%). Sikap yang positif tersebut dapat dilihat dari kuesioner nomor 2. Dalam kuesioner tersebut dinyatakan "Implan merupakan alat kontrasepsi yang memiliki sedikit efek samping" Dari 30 responden 66\% mempunyai sikap positif. Sikap negatif juga dapat dilihat dari kuesioner nomor 14 yang menyatakan "Pemasangan implan akan membutuhkan biaya yang lebih mahal" yang termasuk komponen sikap kognitif. Dari 30 responden 56\% mempunyai sikap negatif dalam menyikapinya.

Sikap bisa dapat dipengaruhi oleh pengalaman pribadi yang telah ada pada diri kita atau yang sedang kita alami akan ikut membentuk dan mempengaruhi penghayatan kita, tanggapan akan menjadi salah satu dasar terbentuknya sikap. Dalam masyarakat sering terlihat bahwa, sikap akseptor $\mathrm{KB}$ 
tentang kontrasepsi implan acuh atau tidak berminat dan para akseptor KB sering menyalah persepsikan kontrasepsi implan.

Selain itu faktor lain yang dapat mempengaruhi sikap adalah sumber informasi. Berdasarkan tabel IV.5 dapat menunjukkan dari 30 responden yang diteliti, terdapat 15 responden $(50 \%)$ sebagian besar mendapat informasi dari Media massa.

Akseptor lebih tertarik pada produk atau program yang dikemas dalam bentuk unik dan menarik, mereka cenderung lebih memilih melihat di $\mathrm{TV}$, radio, majalah, internet, dan lain-lain daripada datang mengunjungi tenaga kesehatan. Hal ini ditunjukkan dengan jumlah responden yang sebagian besar mendapat informasi tentang kontrasepsi implan dari media massa.

Media massa dapat mempengaruhi sikap seseorang yang melihatnya. Terutama TV, internet, dan radio. Karena kata-kata atau bentuk yang digunakan pada media massa dapat menghipnotis pemirsa yang melihatnya.

\section{Hubungan Pengetahuan dengan Sikap Akseptor KB Aktif tentang Kontrasepsi Implan}

Pada hasil uji statistika dengan metode chi-kuadrat $\left(x^{2}\right)$ maka $\mathrm{H}_{\mathrm{a}}$ diterima ini artinya dapat disimpulkan bahwa Ada Hubungan Pengetahuan dan Sikap Akseptor KB Aktif tentang kontrasepsi implan di BPM Ny. Agustina Desa Doko Kecamatan Ngasem Kabupaten Kediri.

Hasil penelitian menunjukkan dari 30 responden yang diteliti, terdapat responden yang mempunyai pengetahuan baik dengan

\section{Simpulan}

1. Pengetahuan akseptor KB aktif tentang kontrasepsi implant dalam kategori baik adalah 18 responden $(60 \%)$

2. Sikap akseptor KB aktif tentang kontrasepsi implan dalam kategori positif adalah 17 responden (57\%) sikap akseptor KB positif sebanyak 7 responden $(23 \%)$.

Sedangkan yang berpengetahuan baik dengan sikap akseptor KB negatif sebanyak 11 responden $(37 \%)$.

Dari hasil penelitian diatas sebagian akseptor KB mempunyai pengetahuan yang baik tentang kontrasepsi implan. Akseptor KB yang berpengetahuan baik dikarenakan sudah mendapat informasi-informasi. Faktor pendidikan juga mempengaruhi akseptor KB dalam pemahaman karena makin tinggi pendidikan seseorang maka semakin banyak seseorang menerima informasi sehingga akseptor $\mathrm{KB}$ dapat memahami tentang kontrasepsi implan.

Dari data yang didapat, ternyata sebagian besar responden yang berpengetahuan baik memiliki sikap negative terhadap kontrasepsi implan. Hal ini dapat terjadi karena setiap responden meiliki sikap berbeda dalam menerima informasi atau pengetahuan.

Pengetahuan responden yang masih cukup dapat di tambah dengan meminta penjelasan dari orang yang lebih mengerti atau petugas kesehatan untuk memberikan penjelasan tentang kontrasepsi implan, sehingga nantinya sikap akseptor dalam menanggapi kontrasepsi implan positif atau baik. Pola pikir seseorang juga dipengaruhi oleh umur karena semakin bertambahnya usia maka semakin berkembang daya tangkap dan pola pikir seseorang. Dan diharapkan pengetahuan seseorang semakin membaik dan meningkat.

3. Ada hubungan pengetahuan dan sikap Akseptor KB Aktif tentang kontrasepsi implan 


\section{DAFTAR PUSTAKA}

Arikunto, Suharsimi. 2010. Prosedur Penelitian Suatu Pendekatan Praktik. Jakarta: Rineka Cipta.

Azwar, Saifudin. 2013. Sikap Manusia. Yogyakarta : Rineka Cipta

Budiman dan Agus, 2013. Kapita Selekta Kuesioner Pengetahuan dan Sikap dalam Penelitian Kesehatan. Jakarta : Salemba Medika.

Bowden, Jan. 2011. Promosi Kesehatan Dalam Kebidanan Prinsip \& Praktik. Jakarta : EGC.

Everett, Suzanne. 2013. Buku Saku Kontrasepsi \& Kesehatan Seksual Reproduktif. Jakarta : EGC.

Handayani, Sri. 2010. Buku Ajar Pelayanan Keluarga Berencana. Yogyakarta : Pustaka Rihama.

Hidayat, Aziz Alimul. 2010. Metode Kebidanan dan Teknik Analisis Data. Jakarta: Salemba Medika.

Hikmawati, Isna. 2011. Promosi Kesehatan untuk Kebidanan. Yogyakarta : Nuha Medika.

Irianto, Koes. 2014. Pelayanan Keluarga Berencana Dua Anak Cukup. Bandung : Alfabeta.

Luknis S. dan Susanto. 2010. Statistic Kesehatan. Jakarta : Rajawali Pers.

Manuaba, IBG. 2009. Memahami Kesehatan Reproduksi Wanita. Jakarta : EGC.

Mubarak, Wahit Iqbal. 2011. Promosi Kesehatan Untuk Kebidanan. Jakarta : Salemba Medika.

Notoatmodjo, Soekidjo. 2007. Promosi Kesehatan \& Ilmu Perilaku. Jakarta: Rhineka Cipta.

Nursalam. 2014. Metodologi Penelitian Ilmu Keperawatan Pendekatan Praktis. Jakarta: Salemba Medika.

Purwandari, Atik. 2010. Ilmu Kesehatan Masyarakat Dalam Konteks Kebidanan. Jakarta : EGC.

Saifuddin, Abdul Bari. 2012. Buku Panduan Praktis Pelayanan Kontrasepsi. Jakarta
: Yayasan Bina Pustaka Sarwono Prawirohardjo.

Sugiyono. 2010. Metode Penelitian Pendidikan. Bandung : Alfabeta

Sujarweni, V. Wiratna. 2014. Metode Penelitian Lengkap, Praktis, dan Mudah Dipahami. Yogyakarta : Pustaka Baru Press.

Sulistyawati, Ari. 2011. Pelayanan Keluarga Berencana. Jakarta : Salemba Medika.

Suratun, dkk. 2008. Pelayanan Keluarga Berencana dan Pelayanan Kontrasepsi. Jakarta: Trans Info Media.

Wawan, A dan Dewi. 2010. Teori \& Pengukuran Pengetahuan, Sikap, dan Perilaku Manusia. Yogyakarta: Nuha Medika.

BKKBN, 2007. Tingkat Pengetahuan Masyarakat tentang Kontrasepsi. http://e-journal.akesrustida.ac.id. [Diakses tanggal : 9 Maret 2015]. 2011. Potensi Penggarapan Program KB. www.bkkbn.go.id. [Diakses tanggal : 9 Maret 2015]. , 2012. BKKBN Jatim Garap Pasar Tradisional. http://jatim.bkkbn.go.id. [Diakses tanggal : 9 Maret 2015].

Blogspot, 2011. Keluarga Berencana. http://zury.blogspot.com. [Diakses tanggal : 17 Maret 2015].

Dinkes RI, 2011. Profil Kesehatan Indonesia. http://www.depkes.go.id. [Diakses tanggal : 6 Maret 2015]. 